\title{
Life cycle assessment of organic and mineral fertilizers in a crop sequence of cauliflower and tomato
}

\author{
R. Quirós · G. Villalba · X. Gabarrell • \\ P. Muñoz
}

Received: 21 July 2014/Revised: 4 January 2015/Accepted: 5 January 2015/Published online: 20 January 2015

(C) Islamic Azad University (IAU) 2015

\begin{abstract}
This study presents a life cycle assessment of a crop sequence of cauliflower and tomato that is subjected to three different fertilization treatments; the crops were cultivated in a Mediterranean region. The main objective of this study is the assessment of organic and mineral fertilizers that are applied to a crop sequence of tomato and cauliflower. Two allocation procedures that are based on the crop cultivation time and the degree of nitrogen mineralization were implemented to allocate the compost burden to the crops. The results indicated that the crops fertilized with home compost achieved the best environmental performance in all impact categories, regardless of the allocation methods, with the exception of marine eutrophication and terrestrial acidification. The comparison of the impact (kg eq. of pollutant/day) on the entire horticultural cycle with the individual crops indicates that cycle yielded the least amount of impact among the assessed categories. The crops that were fertilized with the
\end{abstract}

Electronic supplementary material The online version of this article (doi:10.1007/s13762-015-0756-7) contains supplementary material, which is available to authorized users.

R. Quirós · G. Villalba · X. Gabarrell

Sostenipra Research Group, Institute of Environmental Science and Technology (ICTA), Universitat Autònoma de Barcelona, Edifici C Bellaterra, 08193 Barcelona, Spain

R. Quirós $(\bowtie) \cdot$ G. Villalba $\cdot$ X. Gabarrell

Department of Chemical Engineering XRB, Universitat

Autònoma de Barcelona, Edifici Q Bellaterra,

08193 Barcelona, Spain

e-mail: Roberto.quiros@uab.cat

P. Muñoz

Sostenipra Research Group, Institute of Research in Agrifood

Sector (IRTA), Environmental Horticulture, Cabrils,

08348 Barcelona, Spain home compost using the allocation method, which is based on the degree of nitrogen in the soil, exhibited the least impact value among all categories. However, the allocation procedure based on the cultivation duration was considered to be the better attributional method given the high degree of uncertainty in the nitrogen degradation. This uncertainty is related to the complex interactions among the variables to metabolize the following nutrients (i.e., nitrogen) of fertilizers: variety of crops, crop management, soil type, weather conditions and fertilizer.

Keywords Compost - Impacts · Horticultural · Nitrogen · Soil · Weather

\section{Introduction}

Agriculture is considered to be a major contributor to some existing environmental impacts, such as water pollution, given the intensive use of fertilizers and pesticides (Ongley 1996; European Commission 1999; Laegreid et al. 1999). Fertilizer and pesticide applications affect not only the target crop but also subsequent crops.

A crop sequence is a farming practice in which different crops are grown in the same field at different times over several years. This practice is implemented to promote soil fertility and minimize the development of pests, and weeds while ensuring optimal nutrient management. Multi-cropping systems have several advantages, such as increased production, effective pest, disease and weed control and improved soil health (Ehrmann and Ritz 2013). The timing and crops of a rotation are dependent on the type of farming (arable-mixed or organic/conventional), local climate conditions, soil type, water availability, irrigation, type of crop and potential market opportunities, which are 
key factors in determining not only the yield and the quality of the crops but also their environmental impacts. Essential mineral nutrients must be provided by the soil or by organic and mineral fertilizers. Organic fertilizer can be produced from biodegradable waste via composting (Zaman 2013; Makan et al. 2014) or vermicomposting (Lim et al. 2014a; Shak et al. 2014) or a combination of both types of composting (Wu et al. 2014). Composting a product from the biological decomposition of organic waste is an effective and economic method for the treatment of waste prior to land application (Iqbal et al. 2014).

The concept of recycling waste nutrients and organic matter for use on agricultural land is feasible and desirable (Ayari et al. 2010). The risk of nutrient depletion is latent when the amount of nutrients added to a crop is less than the amount of nutrients removed from the soil in the form of crop yields and residues and the loss of nutrients in the form of volatilization, leaching and erosion. The consequences of nutrient depletion include a decline in soil fertility, crop growth and carbon inputs to the soil and the susceptibility of soil to the negative effects of erosion. Farmers usually employ a large amount of mineral fertilizers to increase the crop yield. The amount of $\mathrm{N}$ fertilizer rapidly increases according to the corresponding crop yield (Zhou et al. 2013). An oversupply of nutrients is the main environmental problem related to fertilizer use. Furthermore, application of mineral fertilizer alone over a long period of time may lead to a higher residual nitrate content in the soil, which increases the risk of leaching (Lim et al. 2014b). However, the application of $\mathrm{N}$ fertilizer will have a minimal effect on increasing yields if other factors are not properly managed (i.e., weather conditions and horticultural practice).

An analysis of the entire life cycle of a crop sequence of cauliflower and tomato, which includes the production, transport and application of compost and mineral fertilizer, was performed in this study.

Three possibilities were considered for the fertilization of cauliflower and tomato: industrial compost (IC), home compost (HC) and mineral fertilizer (MF). The IC was produced from the organic fraction of municipal solid waste (OFMSW). The IC was obtained from a full-scale facility that manages the waste from twelve municipalities that comprise Mancomunitat La Plana in Catalonia. The $\mathrm{HC}$ was produced from the leftover of raw fruit and vegetables (LFRV) and pruning waste (PW) as the bulking agent. The organic material for the $\mathrm{HC}$ was collected from single-family homes in a neighborhood in Barcelona, Catalonia (Quirós et al. 2014a). The fertilization treatment with MF consisted of the application of nitrogen fertilizers $\left(\mathrm{KNO}_{3}\right)$ mixed with water.

The environmental assessment of this study was performed with the life cycle assessment (LCA) methodology, which has been proven to be a valuable tool for the comparison of farming systems at the crop level (Audsley 2007; Gaillard and Hausheer 1999). The LCA is a valuable tool for assessing the application of traditional agricultural products to horticultural (i.e., fruits and vegetables) production systems; it is a recent development with renewed and scientific challenges (Perrin et al. 2014). The LCA in this study was performed according to the guidelines of the ISO 14044 (ISO 2006), and the ReCipe 2008 version 1.05 methodology was used to calculate the environmental impacts. The literature review of the environmental assessments of home compost applications in crop sequence indicated a lack of studies and environmental comparisons of HC, IC and MF.

The first objective of this research is the environmental comparison of three fertilization treatments in a crop sequence using the LCA methodology. The second objective is to evaluate the environmental performance of the system with two allocation procedures for applying the compost to crops. The life cycle impact of the compost was allocated to the two crops according to the physical causality principles stated in ISO 14044 (ISO 2006). Two allocation procedures were implemented to quantify the compost burden: The first procedure was based on the cultivation time (Ta) and the second procedure considered the degree of $\mathrm{N}$ mineralization (NMa) in soil.

The duration of the crop sequence was one calendar year from cauliflower plantation (October 2011) to tomato harvesting (October 2012). The experimental plots were located in the SELMAR research fields in Maresme County in Santa Susana (northwestern Catalonia).

\section{Description of the systems}

Three fertilization treatments (IC, HC and MF) that were applied to a crop sequence of cauliflower and tomato were compared to assess the environmental performance of the single crops and the entire sequence. The three cropping systems were compared with the entire crop sequence. Supplementary Data Figures S1-S3 show the stages and substages of each fertilization treatment. The stages of the LCA were as follows: compost and mineral fertilizer production, compost transport for IC and MF fertilizers, and the cultivation stage. The cultivation stage included the fertirrigation infrastructure and equipment, irrigation, emissions of fertirrigation, machinery used in cultivation (i.e., field preparation and harvesting), carbon sequestration, and nursery and phytosanitary substances.

The compost production stage considered the collection and transport of the OFMSW (collection bin and transport); the electricity, diesel and water consumed in the process; the gaseous emissions of the process $\left(\mathrm{CH}_{4}, \mathrm{NH}_{3}, \mathrm{~N}_{2} \mathrm{O}\right.$ and COVs); the building and machinery and the waste 
management of the infrastructure. The compost transportation for the IC considered transport from the production plant to the plots, including the fuel, truck, truck maintenance, road construction and road maintenance. MF production comprised the extraction of raw material and fertilizer production at the plant, including the infrastructure, the transport of raw materials, the synthesis of the required chemical components, the dosages and the deposition or treatment of generated waste. MF transport considered the distance from the plant to the plots. The transportation of MF was split into two stages: Sea transport from Israel to the Barcelona Port and road transport from the port to the crop plots. The process of the production and transport of MF was adapted from the ecoinvent database (Swiss Centre for Life Cycle Inventories 2013).

Fertirrigation considered the infrastructure and equipment for crop irrigation, transport and waste management. The irrigation substage incorporated the irrigation water and the electricity consumed by the well pump and the irrigation pump. The emissions post-application of fertilizers and water included the emissions of $\mathrm{NH}_{3}, \mathrm{~N}_{2} \mathrm{O}, \mathrm{NO}_{x}$ and $\mathrm{N}_{2}$ to air and the emissions of $\mathrm{NO}_{3}$ to water. The fertirrigation phase considered the machinery and tools needed to prepare the land and to mix and spread the fertilizers (IC and HC), the hours of operation and the fuel consumption. The stage of phytosanitary substances was based on the type of required substances according to the crop, dose and production process.

\section{Materials and methods}

Life cycle assessment

The LCA methodology provides an excellent framework for evaluating municipal solid waste (MSW) management strategies (Lombardi and Carnevale 2013). These management strategies include the application of final products (i.e., compost) from MSW to crops. A life cycle assessment was performed to calculate the environmental impacts of the crop sequence of cauliflower and tomato considering an entire life cycle (production, transport and application to crops) for a 1-year horticultural cycle, including resource extraction and waste disposal. The inventories were constructed based on the guidelines in the ISO 14040-14044 (ISO 2006).

\section{Functional unit and scope}

The functional unit is the basis for the comparison of different systems in a LCA (ISO 2006). The functional unit for the LCA consisted of $1 \mathrm{mt} 2$ of cultivated land for a 1 -year cycle. The inputs and outputs (i.e., energy, resources consumption, yields, impacts) of the inventory stage are related to this functional unit. The scope of the study was limited to compost and mineral fertilizer production, transport and the application to crops. The limits were established by considering all input and output flows of materials and energy according to the system definition.

\section{System boundaries}

The system boundaries included the production of the organic and mineral fertilizers, transport between the production site and the cultivation plots, and all activities related to cultivation, such as fertilization equipment, machinery and tools, pesticides, irrigation and nursery (Supplementary Data Figures S1-S3). The scope of some studies was limited to the production of compost in aerobic and anaerobic biological systems and did not address the application to crops (Lombardi and Carnevale 2013).

\section{Categories of impact and the employed software}

In this study, the ReCipe 2008 version 1.05 (midpoint method, hierarchist version) methodology was used to calculate the environmental impacts. ReCipe emerged as a new methodology in 2000 after a SETAC meeting to combine the CML midpoint and the Pré endpoint approach into a single and consistent methodology. Because this methodology is relatively new, few studies have employed this methodology to assess agricultural systems. In our case study, six impact categories were selected to perform the environmental assessment of the crop sequence for the three fertilization treatments according to ReCipe methodology. The selected categories included climate change (CC), photochemical oxidation formation (POF), terrestrial acidification (TA), freshwater eutrophication (FE), marine eutrophication (ME) and fossil depletion (FD). The cumulative energy demand (CED), which is an energy flow indicator, was also considered (Frischknecht and Jungbluth 2003). The SimaPro version 7.3.3 program (Pré Consultants 2013) was employed for the impact analysis, with the obligatory classification and characterization phases defined by the ISO 14044 (ISO 2006).

\section{Method for preventing the burden of dumping OFMSW and $V F$ in landfills}

The method of cutoff proposed by Ekvall and Tillman (1997) was used to allocate the burden of dumping OFMSW and vegetal fraction (VF) according to ISO 14044. This method dictates that each system is charged with the 
burden for which it was directly responsible. In this study, the environmental burden for dumping the same amount of OFMSW and VF was employed in the calculation of the total burden for IC and HC fertilization treatment. This burden was subtracted from the total impact of the compost production stage. The process used to calculate the environmental charge of dumping compostable material to a landfill was adapted from the ecoinvent database version 2.2 (Swiss Centre for Life Cycle Inventories 2013). The collection and transport of organic waste, including the production of the bin to collect the organic fraction in houses, was also considered. The construction of the landfill and road access, the machinery operation, the combustion of methane without energy recovery, and the consumed land were considered with an impact time limit of 100 years (Doka 2007).

Quality and origin of the data in the inventory

The majority of the data for IC production were locally and experimentally obtained from a full-scale industrial facility for IC in Mancomunitat La Plana, Barcelona and the majority of the data for $\mathrm{HC}$ production was locally and experimentally obtained from homes in Barcelona. Supplementary Data Table S1 shows the origin of the data for IC and HC, respectively. In the case of the cultivation stages, the data were experimentally obtained from real essays in plots located in Santa Susana of Maresme County (Catalonia, Spain). When local information was not available, bibliographical sources and the ecoinvent database 2.2 (Swiss Centre for life cycle Inventories 2010) were used and adapted to the conditions of our systems. Data sources for the cultivation stage and substages are shown in Supplementary Data Table S1.

\section{Life cycle inventory}

The inventories for the production of compost (IC and HC) included the energy (electricity and diesel), water and different elements employed in the process, such as building, tools and machinery. The inventory considered the waste management of these elements (i.e., building, tools and machinery). The different stages and substages for the three fertilization treatments (IC, $\mathrm{HC}$ and MF) are presented in Supplementary Data Figures S1-S3. The inventories for the cultivation stage, which included the consumed energy, water, and resources (machinery, tools and pesticides), are presented in Supplementary Data Table S2. The processes for the cultivation stage inventory were similar to the processes for the two crops, with the exception of the water irrigation system. A microsprinkler was employed for the cauliflower crops, whereas a dripping system was employed for the tomato crops. A complete description of the inventories for the cauliflower crop, which was used as a base to calculate the inventories of the crop sequence, are discussed in Quirós et al. (2014a).

\section{Irrigation water}

Irrigation water was pumped from a nearby well (depth, $10-15 \mathrm{~m}$ ) to the fields using two pumps: The first pump was used to pump the water out of the wells $(4 \mathrm{~kW})$, and the second pump was used to spread the water over the plots $(2.7 \mathrm{~kW})$. Irrigation water measurements were dependent on the evapotranspiration demands. Similar irrigation water was used in the fertilization treatment for each crop (Table 1). The final consumption of water was obtained from meters placed in the plots. The average amount of irrigation water for cauliflower was $109 \mathrm{~L} \mathrm{~m}^{-2}$ for IC, $108 \mathrm{~L} \mathrm{~m}^{-2}$ for $\mathrm{HC}$ and $94 \mathrm{~L} \mathrm{~m}^{-2}$ for MF. In the case of the tomato crops, the average amount of irrigation water was 304,296 and $287 \mathrm{~L} \mathrm{~m}^{-2}$ for IC, $\mathrm{HC}$ and MF, respectively. In this case study, the differences between both crops were attributed to the fact that cauliflower is a winter crop and tomatoes are cultivated during the summer season. The amount of irrigation water for cauliflower was less than the scheduled amount due to the high quantity of rainfall registered at the beginning of cultivation. Although the irrigation water was similar for each crop, small differences were attributable to random causes of the experiment. The irrigation water stage also considered the electricity that was consumed by the pump that was employed to pump water from a well located near the plots and the electricity consumed by the pump to irrigate the plots (Supplementary Data Table S2). As expected, the electricity consumption for the tomato crop exceeded the electricity consumption for the cauliflower crop due to the larger amount of irrigation water applied to the crop.

\section{Compost characterization}

The organic fertilizers (IC and HC) were physically and chemically characterized to determine their quality for use as mineral fertilizer substitutes. Physicochemical characteristics, such as moisture, organic matter, $\mathrm{pH}$, electrical conductivity, N-Kjeldahl, and the dynamic respiration index, and the quality parameters of salmonella and escherichia coli were experimentally measured in a field for IC and HC (Supplementary Data Table S3). The gaseous emissions of $\mathrm{CH}_{4}, \mathrm{NH}_{3}, \mathrm{~N}_{2} \mathrm{O}$ and VOCs that were emitted during the composting process were also experimentally studied for IC and HC. The experimental procedures for the 
Table 1 Total nitrogen provided to crops per fertilization treatment for the two compost allocation procedures and for the mineral fertilizer

\begin{tabular}{|c|c|c|c|c|c|c|c|c|c|c|c|c|c|c|}
\hline & & $\mathrm{L}$ & & Units & Crop seq & quence $^{1}$ & Caul & lower & & $\begin{array}{l}\text { Horti } \\
\text { inacti } \\
\text { GAP }\end{array}$ & $\begin{array}{l}\text { lltural } \\
\text { ity }\end{array}$ & Toma & & \\
\hline & & & & & IC & $\mathrm{HC}$ & IC & $\mathrm{HC}$ & MF & IC & $\mathrm{HC}$ & IC & $\mathrm{HC}$ & MF \\
\hline & & $\mathrm{a}$ & $\begin{array}{l}\mathrm{N} \text { organic content in } \\
\text { compost applied }(\mathrm{dwb})^{2}\end{array}$ & & $2.5 \%$ & $1.7 \%$ & & & & & & & & \\
\hline & & $\mathrm{b}$ & Humidity of compost ${ }^{3}$ & & $39.7 \%$ & $50.3 \%$ & & & & & & & & \\
\hline & & $\mathrm{c}$ & $\mathrm{N}$ content in well water ${ }^{4}$ & $\mathrm{~g} \mathrm{~m}^{-3}$ & 26.052 & & & & & & & & & \\
\hline & & $\mathrm{d}$ & Irrigation water & $1 \mathrm{~m}^{-2}$ & & & 108 & 109 & 94 & - & - & 304 & 296 & 287 \\
\hline & & $\mathrm{e}$ & $\begin{array}{l}\text { N provided by irrigation } \\
\text { water }^{5}\end{array}$ & $\mathrm{~g} \mathrm{~m}^{-2}$ & & & 2.8 & 2.8 & 2.4 & - & - & 7.9 & 7.7 & 7.5 \\
\hline & & $\mathrm{f}$ & $\mathrm{N}$ content in rainfall & g 1 & 0.00076 & & & & & & & & & \\
\hline & & $\mathrm{g}$ & Rainfall & $1 \mathrm{~m}^{-2}$ & & & 529 & 529 & 529 & 220 & 220 & 133 & 133 & 133 \\
\hline & & $\mathrm{h}$ & $\mathrm{N}$ provided by rainfall ${ }^{6}$ & $\mathrm{~g} \mathrm{~N} \mathrm{~m}^{-2}$ & & & 0.40 & 0.40 & 0.40 & 0.17 & 0.17 & 0.10 & 0.10 & 0.10 \\
\hline Allocation & $\mathrm{Ta}$ & $\mathrm{i}$ & Compost allocated to crops ${ }^{7}$ & $\mathrm{~g} \mathrm{~m}^{-2}$ & & & 188 & 274 & - & 158 & 230 & 203 & 296 & - \\
\hline procedures & & $\mathrm{j}$ & $\begin{array}{l}N \text { organic provided by the } \\
\text { compost allocated }^{8}\end{array}$ & $\mathrm{~g} \mathrm{~N} \mathrm{~m}^{-2}$ & & & 2.8 & 2.3 & - & 2.4 & 1.9 & 3.0 & 2.5 & - \\
\hline & & $\mathrm{k}$ & $\mathrm{N}$ total provided to crop ${ }^{9}$ & $\mathrm{~g} \mathrm{~N} \mathrm{~m}^{-2}$ & & & 6.0 & 5.6 & - & 2.5 & 2.1 & 11.1 & 10.3 & - \\
\hline & NM & 1 & $\begin{array}{l}\text { Compost allocated to } \\
\text { crops }^{10}\end{array}$ & $\mathrm{~g} \mathrm{~m}^{-2}$ & & & 151 & 219 & - & 127 & 184 & 163 & 237 & - \\
\hline & & $\mathrm{m}$ & $\begin{array}{l}\mathrm{N} \text { organic provided by the } \\
\text { compost allocated }\end{array}$ & $\mathrm{g} \mathrm{N} \mathrm{m}^{-2}$ & & & 2.2 & 1.9 & & 1.9 & 1.6 & 2.4 & 2.0 & \\
\hline & & $\mathrm{n}$ & $\mathrm{N}$ total provided to $\mathrm{crop}^{12}$ & $\mathrm{~g} \mathrm{~N} \mathrm{~m}^{-2}$ & & & 5.5 & 5.1 & - & 2.1 & 1.7 & 10.4 & 9.8 & - \\
\hline & MF & o & $\begin{array}{l}\text { Dose of mineral fertilizer } \\
\text { applied }\left(\mathrm{KNO}_{3}\right)^{13}\end{array}$ & $\mathrm{~g} \mathrm{~m}^{-2}$ & & & - & - & 6.92 & - & - & - & - & 74.3 \\
\hline & & $\mathrm{p}$ & $\mathrm{N}$ mineral ${ }^{14}$ & $\mathrm{~g} \mathrm{~N} \mathrm{~m}^{-2}$ & & & - & - & 0.96 & - & - & - & - & 10.30 \\
\hline & & $\mathrm{q}$ & $\mathrm{N}$ total provide to crop $^{15}$ & $\mathrm{~g} \mathrm{~N} \mathrm{~m}^{-2}$ & & & - & - & 3.8 & - & - & - & - & 17.9 \\
\hline
\end{tabular}

The letters in the column $\mathrm{L}$ were used for the calculations

$\mathrm{Ta}$ This procedure allocates the compost applied to crops according to the crop duration (since plant cultivation date until fruit harvesting), $\mathrm{NMa}$ this procedure allocates the compost applied to crops according to the degree of $\mathrm{N}$ mineralization in soil, $I C$ industrial compost, $H C$ home compost, $M F$ mineral fertilizer

${ }^{1}$ Crop sequence column refers to data that are common for the two crops

${ }^{2,3}$ Experimentally determined (compost characterization)

${ }^{4}$ The $\mathrm{N}$ content in ground water was 1.86 milliequivalent $\left(26.052 \mathrm{gN} \mathrm{m}^{-2}\right)$

${ }^{5,8} \mathrm{e}=\mathrm{c} \cdot \mathrm{d}$ (conversion factor)

${ }^{6} \mathrm{~h}=\mathrm{f} \cdot \mathrm{g}$

${ }^{7,10}$ See calculation in Table 2

${ }^{8} \mathrm{j}=\mathrm{a} \cdot(1-\mathrm{b}) \cdot \mathrm{i}$

${ }^{9} \mathrm{k}=\mathrm{e}+\mathrm{h}+\mathrm{j}$

$11 \mathrm{~m}=\mathrm{a} \cdot(1-\mathrm{b}) \cdot 1$

$12 \mathrm{n}=\mathrm{e}+\mathrm{h}+\mathrm{m}$

13 Experimentally determined in crop fields

14 Experimentally determined according to $\mathrm{N}$ molecular weight

${ }^{15} \mathrm{q}=\mathrm{e}+\mathrm{h}+\mathrm{p}$

characterization and quantification of gaseous emissions are discussed in Colón et al. (2012) and Lleó et al. (2013) for IC and HC. All values were compared with international and local standards (Spanish legislation) and refer- ences, such as the European Commission for bio-waste management (2008) and the Spanish Royal Decree 506/2013 (Ministerio de la Presidencies 2013). This decree establishes the permitted limits for the concentration of 
heavy metals in compost for use as a mineral fertilizer substitute (Supplementary Data Table S3). The existence of heavy toxic heavy metals in municipal solid waste compost raises significant concerns about the adverse environmental impact of excessive application to agricultural land (Ayari et al. 2010).

The composts (IC and HC) used to fertilize the crops possessed the quality parameters (Spanish Royal Decree 506/2013) for use as a soil amendment and a substitute of mineral fertilizer.

\section{Experimental conditions}

This crop sequence was part of an experimental crop rotation that has been fertilized with organic and mineral fertilizers since 2006. The experimental plots were located in the SELMAR research fields in Maresme County in Santa Susana (northwestern Catalonia, Spain). This site is an experimental open field of the Institut de Recerca i Tecnologia Agroalimentàries (IRTA). Maresme County is a region that is characterized by an intensive crop rotation of several horticultural products (i.e., vegetables).

The region is characterized by a typical Xerothent soil and Mediterranean climate. The land has been used in an intensive crop rotation since 2006 [i.e., chards (2006), tomatoes and cauliflower (2007), onions (2008) and endives (2010)]. In our case, a crop sequence of cauliflower and tomato crops was considered to assess the environmental impacts for a 1-year cycle. Figure 1 provides an overview of the crop sequence.

The experimental field design consisted of three blocks (IC, $\mathrm{HC}$ and MF) with three replicates for each fertilization treatment. Nine blocks in which the area of each block is $46 \mathrm{~m}^{2}$ were designed for the entire crop sequence.

\section{Crop characteristics}

Cauliflower plants (Brassica oleracea L. var. botrytis, commercialized as Trevi) were transplanted on October 6, 2011, using a density of 2.1 plants $\mathrm{m}^{-2}$. The cauliflower was harvested on February 8, 2012, for a cultivation period of 125 days (Fig. 1). The tomato plants (Lycopersicon esculentum Var. Punxa) were transplanted on June 11, 2012, using a density of 0.5 plants $\mathrm{m}^{-2}$. The tomato crop was harvested on October 24, 2012, for a cultivation period of 135 days (Fig. 1).

\section{Horticultural inactivity gap}

A horticultural inactivity gap (HIG) was observed during the crop sequence, during which no plots were cultivated. The HIG extended from February 9, 2012, to June 10, 2012 (Fig. 1). Some experimental conditions (i.e., weather) and agricultural management operations (land preparation and resources) prevented cultivation during this period. In a crop sequence, the environmental burden of the inactivity horticultural periods or any period

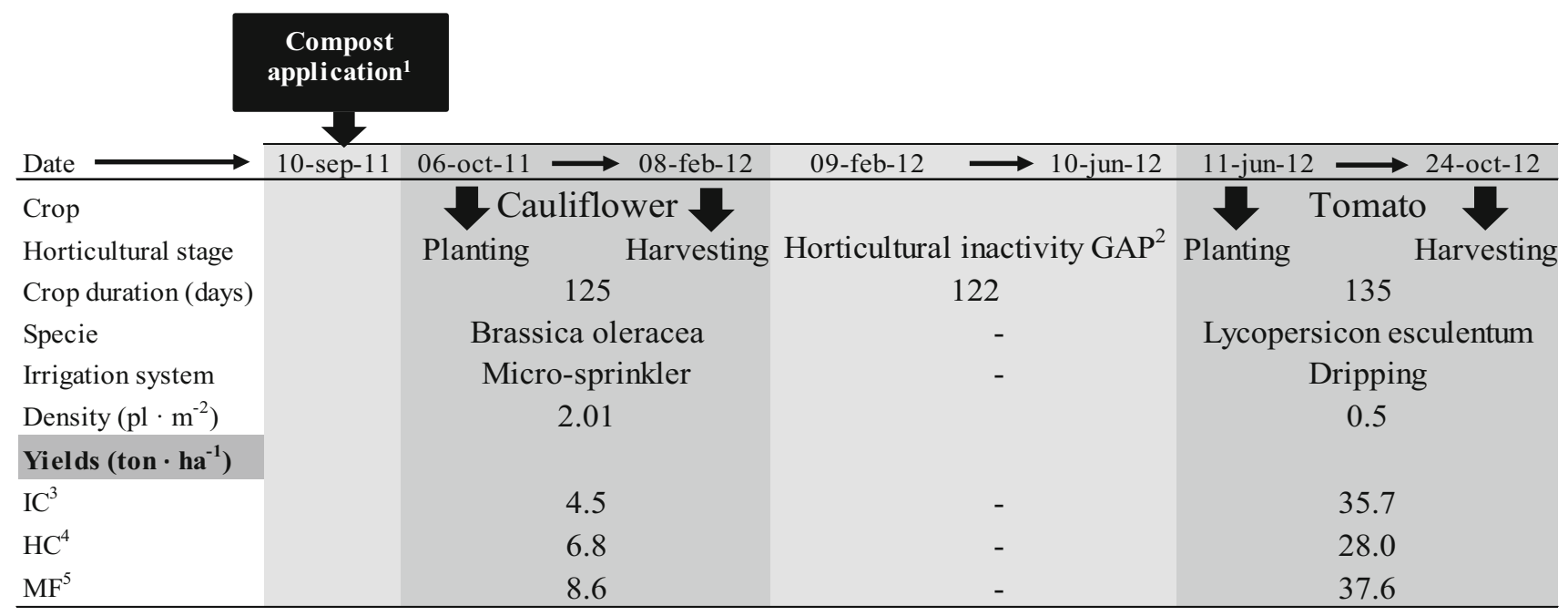

Fig. 1 Summary of the main features of the crop sequence. 1 The composts applied to plot crops were industrial and home compost. 2 There was not cultivation between cauliflower and tomato crops. 3 IC industrial compost. $4 \mathrm{HC}$ home compost. $5 \mathrm{MF}$ mineral fertilizer.
Note: The entire horticultural activity lasted 384 days, a 1-year cycle of 365 days was considered for the crop sequence. The impacts of the horticultural inactivity gap were allocated to the last crop (tomato) 
between the harvesting of a crop and the soil tillage should be attributable to the subsequent crop (Hayer et al. 2010; Martínez-Blanco et al. 2014). In our case of study, the environmental burden of HIG was allocated to the tomato crop. The environmental burden charged to the tomato crop included the emissions to air $\left(\mathrm{NH}_{3}, \mathrm{~N}_{2} \mathrm{O}\right.$ and $\mathrm{N}_{x} \mathrm{O}$ ) due to biological activity and the emissions to water by the leachate of the $\mathrm{NO}_{3}$ that remains in soil during the period of horticultural inactivity.

\section{Weather conditions}

Different weather conditions were observed during the cultivation period for each crop. Climate data were obtained from a weather station that was located next to the crop fields (Santa Susana). In the case of the cauliflower that was planted and harvested during the winter 2011, the average temperature was $12.9{ }^{\circ} \mathrm{C}$ with a rainfall of 200 and $120 \mathrm{~L} \mathrm{~m}^{-2}$ for October 2011 and the first 2 weeks of November 2011, respectively (RuralCat 2013). These weather conditions were considered atypical compared with the weather conditions during the same period in previous years, in which an average temperature of $11^{\circ} \mathrm{C}$ was recorded (RuralCat 2013). These weather conditions primarily affected the nitrogen mineralization and the leachate of fertilizers. These weather conditions delayed the application of mineral fertilizer and negatively affected the yield of fruits for the three fertilization treatments. For the tomato crop that were cultivated during summer 2012, an average temperature of $22{ }^{\circ} \mathrm{C}$ and a rainfall of $122 \mathrm{~L} \mathrm{~m}^{-2}$ were recorded during the cultivation period (RuralCat 2013). The weather conditions for this crop were similar to the weather conditions in previous years for the same period.

\section{Water and fertilizer application}

The cauliflower crop was irrigated 3-4 times per week, and the tomato crop was irrigated daily. The water dose was based on the tensiometer reading and evapotranspiration. To irrigate the crops, we employed the most common practices in the region. The cauliflower crop was irrigated using a micro-sprinkler system, and the tomato crop was irrigated with a dripping system (Fig. 1). The IC and HC were directly applied to land with agricultural machinery at the beginning of the cauliflower crop (September 2011). The mineral fertilizer was mixed and applied with the irrigation water. Table 1 shows the dose of organic fertilizer that was applied to the crops for the two compost allocation procedures (Ta and $\mathrm{NMa}$ ) and the dose of mineral fertilizer and the amount of irrigation water applied to each crop.
The fertilizer doses were experimentally calculated by considering the soil nutrient content and the nutrient requirements of the crops. Similar quantities of fertilizer were applied in each fertilization treatment (Table 1), with the exception of each cauliflower crop, in which the quantity of MF was considerably lower compared with the tomato crop. The low quantity of mineral fertilizer applied to the cauliflower crop was attributed to the large quantity of rainfall at the beginning of cultivation.

The organic fertilizer (compost) is generally applied to satisfy the nutrient requirements of several crops in 1-2 year cycles. In this study, the compost was assumed to be applied to satisfy the nutrient requirements of two calendar years (720 days). The total amount of compost that was applied to the land for the crop sequence was $1.1 \mathrm{~kg} \mathrm{~m}^{-2}$ for IC and $1.6 \mathrm{~kg} \mathrm{~m}^{-2}$ for HC (Table 2). As previously explained, two procedures of compost allocation to the crops ( $\mathrm{Ta}$ and $\mathrm{NMa}$ ) were evaluated in this study to assess the environmental performance of the systems.

The amounts of irrigation water applied to each crop in the three fertilization treatments (IC, $\mathrm{HC}$ and MF) were similar, as shown in Table 1. According to Directive 91/676 (European Economic Community 1991), the high concentration of nitrogen in the ground water (1.86 milliequivalent of $\mathrm{NO}_{3}^{-}=115.32 \mathrm{~g} \mathrm{NO}_{3}^{-} \mathrm{m}^{-3}$ ) near the experimental plots exceeded the permissible limit $(50 \mathrm{~g}$ $\mathrm{NO}_{3}{ }^{-} \mathrm{m}^{-3}$ ). Therefore, the nitrogen concentration in the ground water was considered as a contribution of nutrients to the crops (Table 1).

\section{Degree of nitrogen mineralization}

$\mathrm{N}$ mineralization can occur during two main phases: the compost production phase and after the application of compost in soil. During composting, approximately $50 \%$ of added organic matter is completely mineralized due to the degradation of easily degradable compounds, such as proteins, cellulose and hemicellulose by microorganisms (Sudharsan and Kalamdhad 2014).

The compost is characterized as a slow release-nutrient fertilizer, which is typically applied to fulfill an entire cropping plan. The degree of $\mathrm{N}$ mineralization after the application of compost can significantly vary. Several causes affect the mineralization of $\mathrm{N}$ in soil, such as composition and maturity of the compost, climatic conditions and management practices. Several rates for the mineralization of nitrogen have been determined by researchers, such as Martínez-Blanco et al. (2014), who considered rates between 5 and $22 \%$ for the first year of compost application and 40-50\% for the subsequent 3-5 years. Experts on compost production and its application in the Catalonia region reported rates of $60 \%$ of the 
Table 2 Compost applied to crops for the two allocation procedures

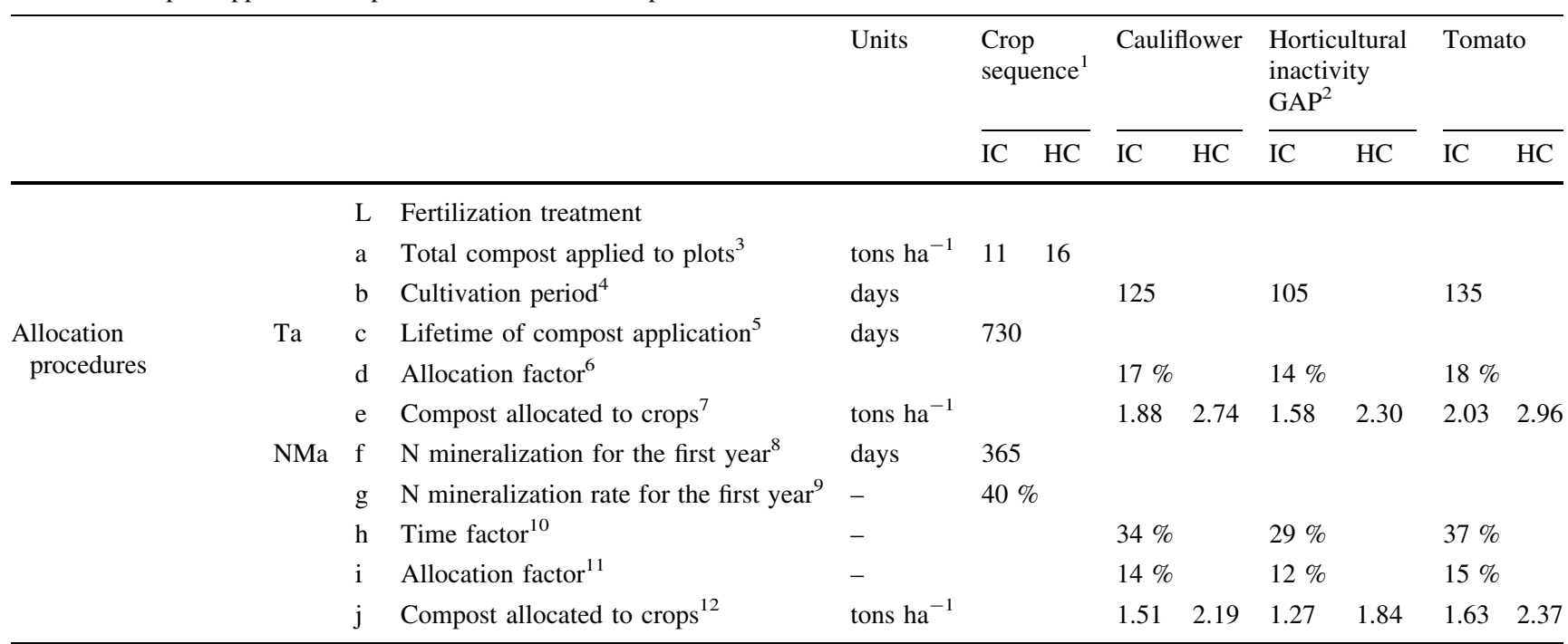

The letters in the column $\mathrm{L}$ were used for the calculations

$\mathrm{Ta}$ This procedure allocates the compost applied to crops according to the crop duration (since plant cultivation date until fruit harvesting), $\mathrm{NMa}$ this procedure allocates the compost applied to crops according to the degree of $\mathrm{N}$ mineralization in soil, IC industrial compost, $H C$ home compost

${ }^{1}$ Crop sequence column refers to data that is common for the two crops

2 There was not crop during the period from February 16, 2012, to June 10, 2012

3 The composts were applied to plots at the beginning of the crop sequence

${ }^{4}$ Cultivation period refers to the duration of crop since plantation to harvesting. A horticultural inactivity GAP of 105 days was considered between the two crops

${ }^{5}$ It was considered for the Ta (allocation procedure) that the compost is applied to plots every two years

$6 \mathrm{~d}=\mathrm{b} / \mathrm{c}$

$7 \mathrm{e}=\mathrm{a} \cdot \mathrm{d}$

8 The period considered for the $\mathrm{N}$ mineralization for the NMa procedure was one calendar year

${ }^{9}$ It was considered a constant degree of $\mathrm{N}$ mineralization of $40 \%$ for the first year (365 days)

${ }^{10} \mathrm{~h}=\mathrm{b} / \mathrm{f}$

${ }^{11} \mathrm{i}=\mathrm{g} \cdot \mathrm{h}$

${ }^{12} \mathrm{j}=\mathrm{a} \cdot \mathrm{i}$

available nitrogen in the soil during the first year and $40 \%$ of the available nitrogen for the second year (Bernat et al. 2000). For this study, a rate of $40 \%$ was used to calculate the mineralization of the $\mathrm{N}$ available in the compost (IC and HC). This degree of $\mathrm{N}$ mineralization in soil was considered for the first year of compost application; it is assumed to be a constant degradation rate over time. The remaining $\mathrm{N}$ in soil will mineralize at a constant rate of $20 \%$ for the second year until the entire mineralization cycle is completed over time.

\section{Nitrogen provided to crops}

The $\mathrm{N}$ provided to crops (Table 1) was derived from three sources: irrigation water, rainfall and organic (IC and $\mathrm{HC}$ ) and mineral fertilizers (MF). The $\mathrm{N}$ content in the irrigation water (1.86 milliequivalent of $\mathrm{N}=26.1 \mathrm{gN} \mathrm{m}^{-3}$ ) was experimentally measured from the groundwater obtained from a well located near the plots. The $\mathrm{N}$ in rainfall was $0.00076 \mathrm{~L} \mathrm{~m}^{-2}$. The $\mathrm{N}$ concentration in the organic fertilizer (IC and HC) was experimentally measured from samples (Supplementary Data Table S3). The $\mathrm{N}$ supplied by the organic fertilizer varied according to the allocation method. As previously explained, the first allocation method was based on the cultivation time (from plantation to harvesting) and the second allocation method considered the degree of $\mathrm{N}$ mineralization (i.e., $40 \%$ for the first year). The doses of organic fertilizer that were applied to $\mathrm{KNO}_{3}$ were also experimentally calculated by con- 
Table 3 Nitrogen uptake by crops per $\mathrm{m}^{2}$ and plant

\begin{tabular}{|c|c|c|c|c|c|c|c|}
\hline & \multirow[t]{3}{*}{ Units } & \multicolumn{6}{|c|}{ Crop sequence } \\
\hline & & \multicolumn{3}{|c|}{ Cauliflower } & \multicolumn{3}{|c|}{ Tomato } \\
\hline & & IC & $\mathrm{HC}$ & $\mathrm{MF}$ & IC & $\mathrm{HC}$ & $\mathrm{MF}$ \\
\hline Yield $^{\mathrm{a}}$ & $\mathrm{g}$ dry matter $\mathrm{m}^{-2}$ & 342 & 353 & 319 & 709 & 619 & 836 \\
\hline $\mathrm{N}$ uptake & $\mathrm{g} \mathrm{N} \mathrm{m}^{-2}$ & 28 & 26 & 27 & 22 & 16 & 21 \\
\hline Plantation density & $\mathrm{pl} \mathrm{m}{ }^{2}$ & 2.1 & 2.1 & 2.1 & 0.5 & 0.5 & 0.5 \\
\hline Yield & $\mathrm{g}$ dry matter $\mathrm{pl}^{-1}$ & 164 & 169 & 153 & 1,418 & 1,239 & 1,672 \\
\hline $\mathrm{N}$ uptake & $\mathrm{g} \mathrm{N} \mathrm{pl}^{-2}$ & 13 & 12 & 13 & 44 & 31 & 43 \\
\hline
\end{tabular}

$I C$ Industrial compost, $H C$ home compost, $M F$ mineral fertilizer

${ }^{\text {a }}$ Samples of plants were analyzed to determine $\mathrm{N}$ content in the biomass (fruit, leaves and stem)

Table 4 Carbon sequestration per crop and fertilization treatment for the two allocations procedures and for the compost applied to crops

\begin{tabular}{|c|c|c|c|c|c|c|c|c|c|c|c|c|}
\hline & & \multirow[b]{2}{*}{$\mathrm{L}$} & \multirow[b]{2}{*}{ Fertilization treatment } & \multirow[b]{2}{*}{ Units } & \multicolumn{2}{|c|}{$\begin{array}{l}\text { Crop } \\
\text { sequence }^{1}\end{array}$} & \multicolumn{2}{|c|}{ Cauliflower } & \multicolumn{2}{|c|}{$\begin{array}{l}\text { Horticultural } \\
\text { inactivity } \\
\mathrm{GAP}^{2}\end{array}$} & \multicolumn{2}{|c|}{ Tomato } \\
\hline & & & & & IC & $\mathrm{HC}$ & $\mathrm{IC}$ & $\mathrm{HC}$ & IC & $\mathrm{HC}$ & IC & $\mathrm{HC}$ \\
\hline & & a & $\mathrm{C}$ content in compost ${ }^{3}$ & $\mathrm{~g} \mathrm{~kg}$ of compost ${ }^{-1}$ & 161 & 344 & & & & & & \\
\hline \multirow[t]{6}{*}{ Allocation procedures } & $\mathrm{Ta}$ & $\mathrm{b}$ & Compost allocated to crops ${ }^{4}$ & $\mathrm{~g} \mathrm{~m}^{-2}$ & & & 188 & 274 & 158 & 230 & 203 & 296 \\
\hline & & $\mathrm{c}$ & $\mathrm{C}$ content in compost applied ${ }^{5}$ & $\mathrm{~g} \mathrm{~m}^{-2}$ & & & 30 & 94 & 25 & 79 & 33 & 102 \\
\hline & & $\mathrm{d}$ & C sequestration ${ }^{6}$ & $\mathrm{~g} \mathrm{~m}^{-2}$ & & & 2.4 & 7.5 & 2.0 & 6.3 & 2.6 & 8.1 \\
\hline & $\mathrm{NMa}$ & $\mathrm{e}$ & Compost allocated to crop ${ }^{7}$ & $\mathrm{~g} \mathrm{~m}^{-2}$ & & & 151 & 219 & 127 & 184 & 163 & 237 \\
\hline & & $\mathrm{f}$ & $\mathrm{C}$ content in compost applied ${ }^{8}$ & $\mathrm{~g} \mathrm{~m}^{-2}$ & & & 24 & 75 & 20 & 63 & 26 & 81 \\
\hline & & $\mathrm{g}$ & C sequestration ${ }^{9}$ & $\mathrm{~g} \mathrm{~m}^{-2}$ & & & 1.9 & 6.0 & 1.6 & 5.1 & 2.1 & 6.5 \\
\hline
\end{tabular}

The letters in the column $\mathrm{L}$ were used for the calculations

$\mathrm{Ta}$ Time allocation procedure allocates compost applied according to cultivation time, $N M a \mathrm{~N}$ mineralization procedure allocates compost applied according to the $\mathrm{N}$ mineralization in soil, $I C$ industrial compost, $H C$ home compost

${ }^{1}$ Crop sequence column refers to data that are common for the crops

2 There was not crop during the period from February 16, 2012, to June 10, 2012. The carbon sequestered was allocated in the environmental assessment proportionally to crop according to the allocation procedure

3 The $\mathrm{C}$ content in compost was experimentally determined (compost characterization)

4,7 The compost was allocated according to the two allocation procedures (Table 2)

${ }^{5} \mathrm{c}=\mathrm{a} \cdot \mathrm{b} / 1,000$ (conversion factor $\mathrm{kg} \mathrm{g}^{-1}$ )

${ }^{6} \mathrm{~d}=\mathrm{c} \cdot 8 \%$, it was considered that $8 \%$ of $\mathrm{C}$ contained in the compost applied is retained in soil after 100 years

${ }^{8} \mathrm{~g}=\mathrm{a} \cdot \mathrm{f} / 1,000$ (conversion factor $\mathrm{kg} \mathrm{g}^{-1}$ )

${ }^{9} \mathrm{~h}=\mathrm{g} \cdot 8 \%$

sidering the type of crop and the available nitrogen in the soil.

\section{Nitrogen uptake by crops}

The $\mathrm{N}$ uptake by the fruits was experimentally measured from biomass samples per $\mathrm{m}^{-2}$ and per plant for the three fertilization treatments. The $\mathrm{NO}_{3}{ }^{-}$and $\mathrm{N}$ concentrations were performed according to the method of Keeney and Nelson (1982). The total and marketable yield in the entire plot area was determined at harvest time. The plants, which were sampled in the harvest period, were dried at $65{ }^{\circ} \mathrm{C}$ until a constant weight was achieved and its $\mathrm{N}$ content in fruits, leaves and stems were analyzed by the Kjeldahl method (Doltra and Muñoz 2010). The $\mathrm{N}$ uptake by $\mathrm{m}^{2}$ and the plant is presented in Table 3 .

\section{Carbon sequestration}

The sequestration of $\mathrm{C}$ into the soil can be considered as the removal of $\mathrm{C}$ from the atmosphere and translated to saved $\mathrm{CO}_{2}$ emissions, which are directly related to the 
category of "global warming." According to Smith et al. (2001), the carbon sequestration has been recognized by the Intergovernmental Panel on Climate Change (IPCC 2006) as one of the possible measures to mitigate greenhouse gas emissions.

Carbon sequestration is calculated as a percentage of the added carbon in the treated organic waste that is permanently bound in the soil (Hansen 2006). After the compost is produced and applied to the land, it continues to degrade and releases carbon dioxide and forms humic compounds. We assumed that only $8.2 \%$ of the $\mathrm{C}$ concentration in compost remains in soil 100 years after its application and that the remaining $91.8 \%$ of the $\mathrm{C}$ concentration will be mineralized to $\mathrm{CO}_{2}$ over time (Smith et al. 2001). The calculated carbon sequestration for each crop was considered to be a negative contribution to the total greenhouse gas emissions. Table 4 shows the carbon sequestration per crop for the two compost allocation procedures (Ta and NMa).

\section{Results and discussion}

This section presents the analysis of the results for the experimentally measured agricultural parameters and the environmental assessment of the systems. The main parameters consisted of the yield, the nitrogen uptake by the crops, the degree of $\mathrm{N}$ mineralization in soil and the carbon sequestration. The environmental assessment consisted of the stages and substages and for the total impacts. Similarly, the analysis for the total impacts was split by crops, fertilization treatments and the allocation procedure used to allocate the compost applied to the plots.

\section{Yield}

The total yield varied according to the crops and fertilization treatments. As shown in Fig. 1, the crops (cauliflower and tomato) that were fertilized with MF yielded the best agronomical performance. The yield for the cauliflower crop fertilized with $\mathrm{MF}$ was 26 and $91 \%$ higher than the cauliflower crop fertilized with IC and $\mathrm{HC}$. The yield for the tomato crops fertilized with $\mathrm{MF}$ and $\mathrm{HC}$ was the same for both $\mathrm{MF}$ and $\mathrm{HC}$, whereas the tomato crop fertilized with IC was $28 \%$ higher than the tomato crops fertilized with MF and HC (Fig. 1). The weather conditions negatively affected the cauliflower yield. Significant rainfall at the beginning of the cultivation period caused fertilizer leachate and nutrient loss (nitrogen). The rain delayed the MF application with the consequent reduction of the applied quantity due to the compost applied to satisfy the nutrient requirements for a cycle of 2 years until the next application; therefore, the nutrient loss due to significant rainfall also negatively affected the tomato yield. The quantity and availability of the fertilizers are crucial for the crop yield. For example, because the nutrients in MF are already mineralized in the form of $\mathrm{NO}_{3}$, they are almost immediately available to be assimilated by the crops for metabolic processes. The organic fertilizers (compost) are characterized by a slow nutrient release, in which the conversion process is highly dependent on several variables, such as the nutrient concentration, the maturity and stability of the compost, the cultivation management and the weather conditions.

A literature review revealed a lack of data for cauliflower and tomato yields under similar cultivation management. For different conditions (i.e., different doses of fertilizer and weather conditions), Martínez-Blanco et al. (2011) obtained commercial yields that were 1 and 10 times higher for cauliflower crops and tomato crops, respectively, that were fertilized with MF. The higher yields applied to these crops were favored by the weather conditions and the higher dose of MF applied to the crops. The tomato crop was a traditional variety (Lycopersicom esculemtum Var. Punxa), which typically presents inferior yields compared with the cultivated variety (Lycopersicom esculemtum Var. Elvirado). However, the yields in the current essay $\left(2-4 \mathrm{~kg} \mathrm{~m}^{-2}\right.$ for a density of $0.5 \mathrm{pl} \mathrm{m}^{-2}$ ) were similar to the yields detailed in Casals and Pascual (2011) (2-3 $\mathrm{kg} \mathrm{m}^{-2}$ for a density of $0.5 \mathrm{pl} \mathrm{m}^{-2}$ ) for the same variety (Lycopersicom esculemtum Var. Punxa).

\section{Supplied nitrogen and uptake by crops}

As shown in Table 1, the total $\mathrm{N}$ supplied to the crops by the applied compost was similar to the fertilization treatments (IC and HC) for the same crop and compost allocation procedure. For the cauliflower crop, the total $\mathrm{N}$ supplied by MF was lower than the total IC and HC. The differences between the MF, IC and $\mathrm{HC}$ ranged from 25 to $37 \%$ depending on the fertilization treatment and the compost allocation procedure. The total concentration of supplied $\mathrm{N}$ by the MF for the tomato crop was higher than the total concentration of supplied $\mathrm{N}$ by the IC and HC. In this case, the differences varied between 62 and $73 \%$ depending on the fertilization treatment and the compost allocation procedure. 
As shown in Table 1, the quantity of MF supplied to the tomato crop was fourfold higher than the quantity of MF supplied to the cauliflower crop because tomato crops are a more nutrient-demanding crop than cauliflower. The large quantity of rainfall at the beginning of the cultivation period delayed the application and quantity of MF for the cauliflower crop.

The $\mathrm{N}$ uptake was similar for identical crops regardless of the fertilization treatment (Table 3). The results show that the $\mathrm{N}$ uptake $\left(\mathrm{gN} \mathrm{pl}^{-1}\right)$ was considerably higher in the tomato crop. Depending on the fertilization treatment, the $\mathrm{N}$ uptake $\left(\mathrm{gN} \mathrm{pl}^{-1}\right)$ for the tomato crop was approximately two to threefold higher than the cauliflower crop. The low quantity of $\mathrm{N}$ uptake by the tomato crop for the case of $\mathrm{HC}$ $\left(31 \mathrm{gN} \mathrm{pl}^{-1}\right)$ was considered to be a special case, which was attributable to the random conditions of the experiment.

The approximate balance of $\mathrm{N}$ between the $\mathrm{N}$ uptake (Table 3) and the supplied $\mathrm{N}$ (Table 1) indicated that a significant part of the $\mathrm{N}$ uptake was supplied by the soil in both crops. The $\mathrm{N}$ uptake for cauliflower was an average of $27 \mathrm{gN} \mathrm{m}^{-2}$ for the three fertilization treatments (IC, HC and MF) The average $\mathrm{N}$ supplied to the crop was $5 \mathrm{gN} \mathrm{m}^{-2}$. Almost $22 \mathrm{gN} \mathrm{m}^{-2}$ (440\%) of the $\mathrm{N}$ uptake was sourced by the $\mathrm{N}$ storage in soil. For the tomato crop, the $\mathrm{N}$ uptake (average of $19 \mathrm{gN} \mathrm{m}^{-2}$ ) for IC and $\mathrm{HC}$ was less than the $\mathrm{N}$ supplied which was $11 \mathrm{gN} \mathrm{m}^{2}$ in average. In the case of MF for the tomato crop, the $\mathrm{N}$ uptake $\left(21 \mathrm{gN} \mathrm{m}^{2}\right)$ was $3 \mathrm{gN} \mathrm{m}^{2}$ higher than the supplied $\mathrm{N}$ $\left(18 \mathrm{gN} \mathrm{m}^{2}\right)$. The results indicated that the soil of the experimental plot operated as s reservoir of $\mathrm{N}$, which was applied with the fertilizers (organics or minerals) to the previously cultivated crops.

\section{Carbon sequestration}

The carbon sequestration was reduced from the total impact for the CC category. As shown in Fig. 2, the carbon sequestration represented a significant contribution (i.e., 3-18\% of the total impact) in the environmental performance of the systems for the global warming potential. The results of carbon sequestration varied depending on the crop and fertilization treatment; the highest values for the carbon sequestration were attained for the crops fertilized with HC. Regardless of the allocation procedure for the compost applied to crops, the carbon sequestration was approximately three times higher for the systems fertilized with HC (Table 4). As shown in Table 4, the higher quantity of carbon sequestration for $\mathrm{HC}$ systems was attributed to the significant quantity of applied compost and the high concentration of
C, which was two times larger compared with IC systems. Regardless of the fertilization treatments (IC and HC), the carbon sequestration was $25 \%$ higher for the time allocation procedure ( $\mathrm{Ta}$ ) compared with the allocation procedure based on the degree of $\mathrm{N}$ mineralization (NMa) in soil. The differences between the allocation procedures were attributed to the higher quantity of compost allocated by Ta compared with the NMa procedure. Similarly, the Ta procedure had an allocation factor that was slightly higher $(2-3 \%)$ than the calculated allocation factor for NMa (Table 2).

Environmental assessment

\section{Environmental assessment by stages and substages}

Figure 2 presents the environmental impacts for the different stages and substages per crop type, category and fertilization treatment. Figure 2a, b shows that the compost production stage, which considers elements such as energy, water, and building and process emissions, was the greatest impact contributor for POF and TA. These results were obtained for both crops (cauliflower and tomato) fertilized with IC. The impacts for these categories were primarily produced by the $\mathrm{NH}_{3}$ emitted during the composting process. For the remaining categories (CC55, FE, ME, FD and CED), the impacts for both crops predominantly varied with the stages related to the cultivation phase. The fertirrigation stage (i.e., primary pipe) was the highest impact contributor for the CC, FE, FD and CED categories for the cauliflower crop fertilized with IC, whereas the irrigation stage showed the greatest impacts in CC, FD and CED for the tomato crop, which received more irrigation than cauliflower. In these categories, the impacts were caused by the electricity consumed for the two pumps that were used to pump the water from the well and irrigate the crops.

Figure $2 \mathrm{c}, \mathrm{d}$ shows the impacts for the cauliflower and tomato crops that were fertilized with $\mathrm{HC}$, respectively. The machinery and tools used in the tillage operations (i.e., soil preparation and compost application) represented the highest impacts for cauliflower in the majority of categories (CC, POF and FD), as shown in Fig. 2c. For the tomato crop, the stages of machinery and tools and irrigation were the greatest contributors for the largest number of categories (CC, POF, FE, FD and CED). As shown in Fig. 2c, d, the carbon sequestration for both crops represented a negative contribution in the $\mathrm{CC}$ category. The results showed that the carbon sequestration was two times higher for the crops fertilized with HC compared with IC, which is attributed to a larger content of C (344 $\mathrm{g} \mathrm{kg}$ of compost ${ }^{-1}$ ) 
Fig. 2 Total environmental impacts contribution by stages per fertilization treatment and crop. *This stage considers emissions to air $\left(\mathrm{NH}_{3}, \mathrm{~N}_{2} \mathrm{O}\right.$ and $\left.\mathrm{NO}_{x}\right)$ and water $\left(\mathrm{NO}_{3}\right)$ from fertilizer applied. The impact is accounted for NMa allocation procedures (a)

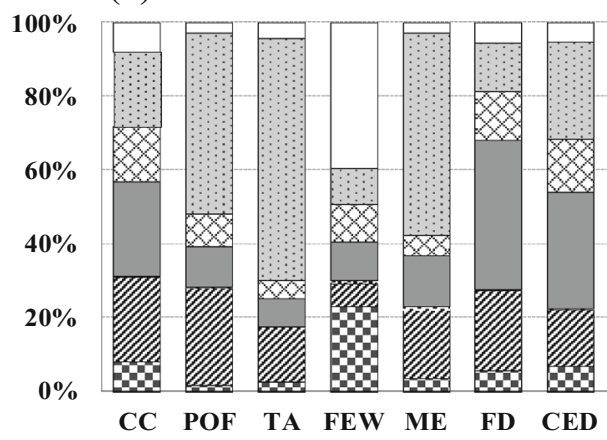

(c)

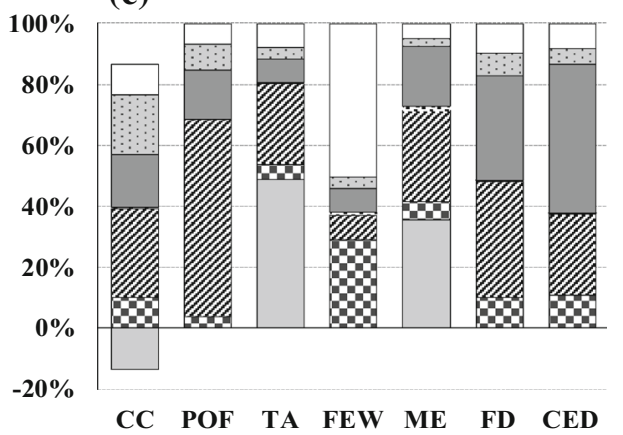

(e)

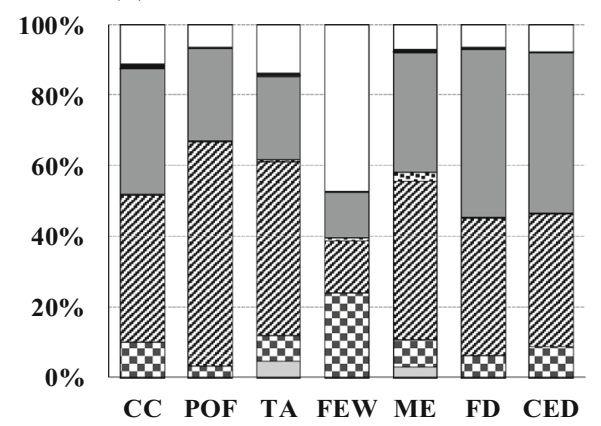

(b)

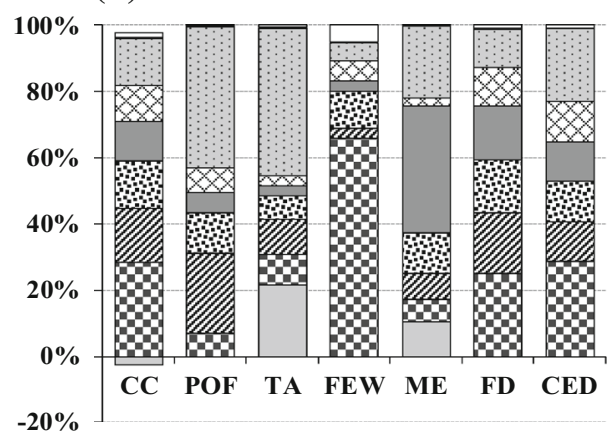

(d)

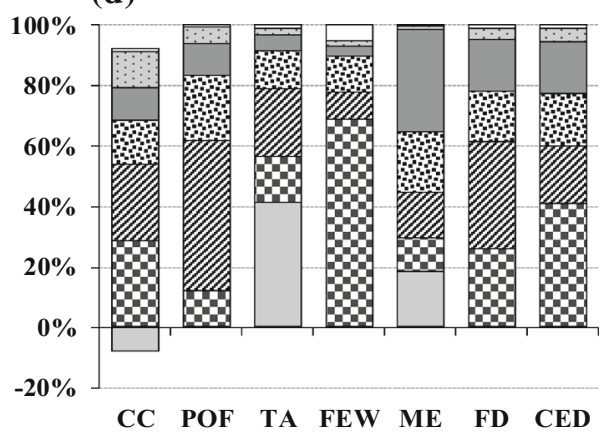

(f)

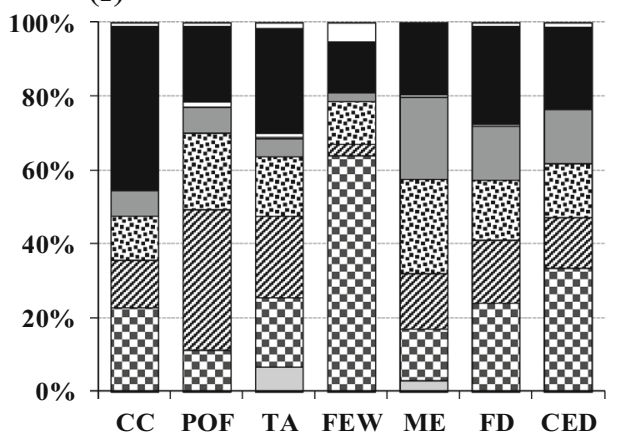

\begin{tabular}{|c|c|c|}
\hline Compost production & Mineral fertilizer production & 8 Compost transport \\
\hline 三 Mineral fertilizer transport & Fertirrigation & Phytosanitary substances \\
\hline $\mathscr{W}$ Machinery and tools & B Irrigation & $\square$ Cultivation emissions ${ }^{*}$ \\
\hline Nursery & & \\
\hline
\end{tabular}

(Table 4) in HC and the large application of HC (16 ton$\mathrm{s} \mathrm{ha}^{-1}$ ) to the crops (Table 2).

The comparison of MF with IC and HC reveals a significant difference in the environmental assessment of the systems (Fig. 2d, e). The machinery and tools and fertirrigation stages had the greatest effect on the environmental performance of the cauliflower crop. The mineral fertilizer production, the phytosanitary substances and irrigation stages yielded the greatest contribution to the environmental performance of the tomato crop. The large application of $\mathrm{MF}\left(\mathrm{KNO}_{3}\right)$ to the tomato crop, which was eleven times larger than the application to the cauliflower crop (Table 1) and the large application of irrigation water to the tomato crop, which was almost three times larger than the 
application of irrigation water to the cauliflower crop, explained the differences between the impacts of the two systems. The high quantity of water applied to the tomato crop considerably affected other stages (i.e., irrigation) due to the electricity consumption by the two pumps that were used to pump water from the well and irrigate the crop plots.

\section{Total environmental assessment}

As shown in Fig. 3, the systems were classified according to crop type (cauliflower and tomato), fertilization treat- ment (IC, $\mathrm{HC}$ and MF) and the allocation procedure used to allocate the compost applied to the crops (Ta and $\mathrm{NMa}$ ). Regardless of the fertilization treatment and the compost allocation procedure, the cauliflower crop exhibited a better environmental performance than the tomato crop for all impact categories. The high quantity of irrigation water and fertilizer demonstrated the largest impact on the performance of the tomato crop. For the tomato crop, the irrigation implied the use of more pumphours and a major electricity consumption by the use of pumps to pump water from the well and irrigate the plots. A larger application of compost to the tomato crop
Fig. 3 Total impacts per fertilization treatment, allocation procedure and impact category
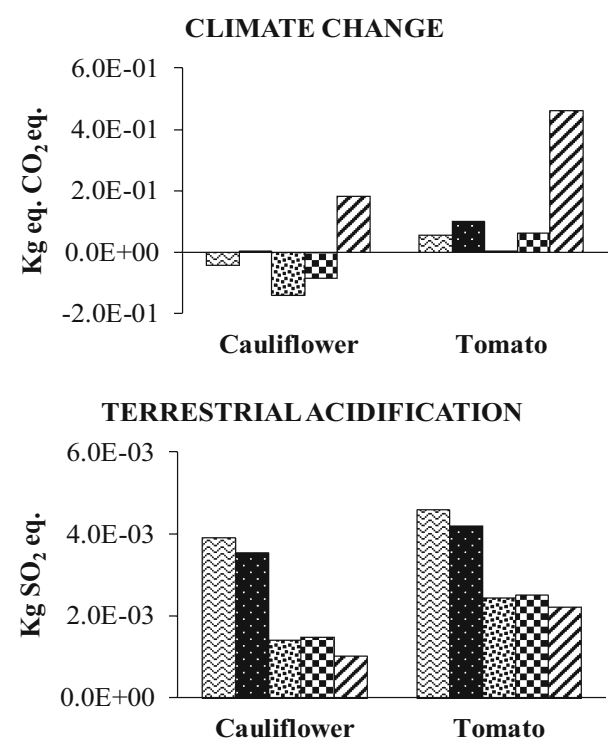

MARINE EUTROPHICATION
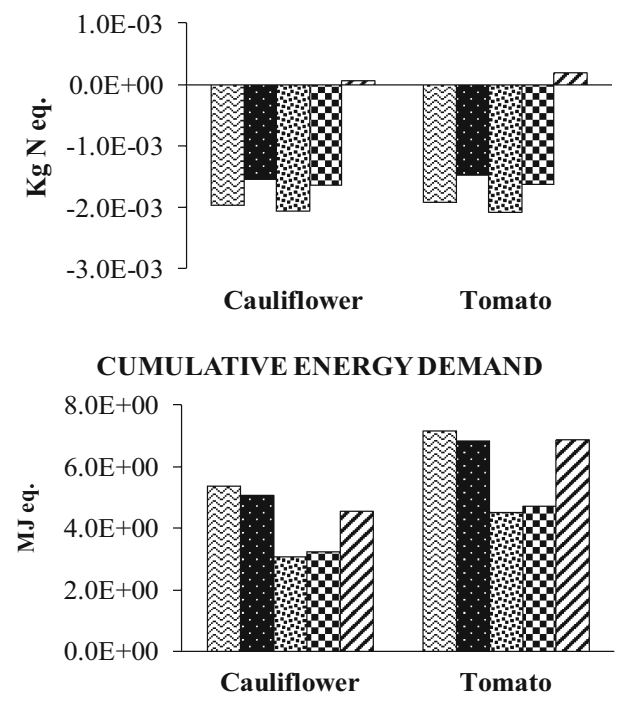

PHOTOCHEMICAL OXIDATION FORMATION
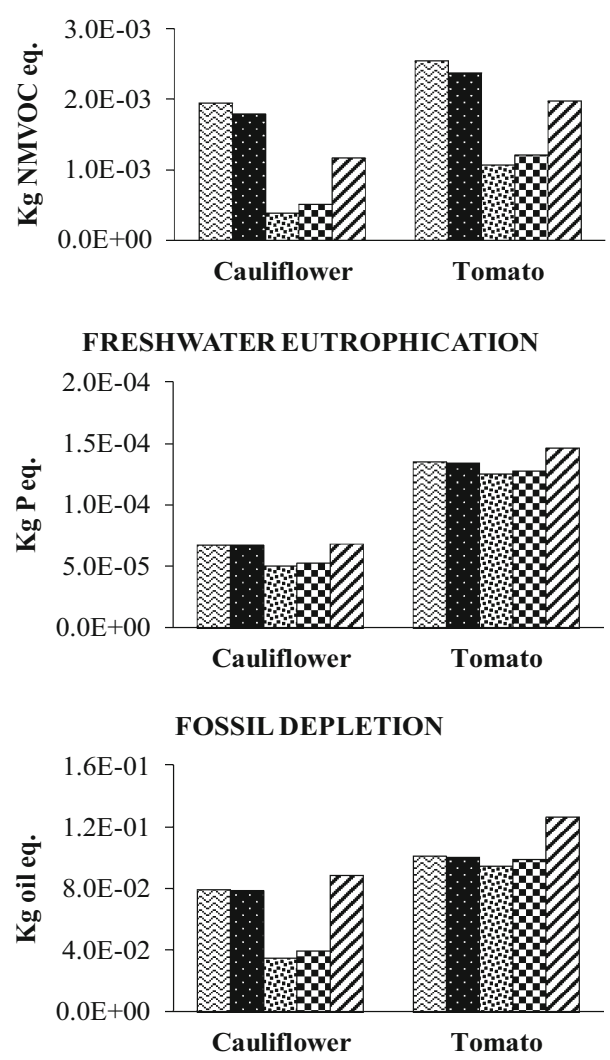

₹ Industrial compost_time allocation

Industrial compost_degree mineralization Fis Home compost_time allocation

6 Home compost_degree mineralization nitrogen ए/ Mineral fertilizer 
Fig. 4 Environmental comparison (unit eq. of pollutant element/day) between single crops and the entire crop cycle

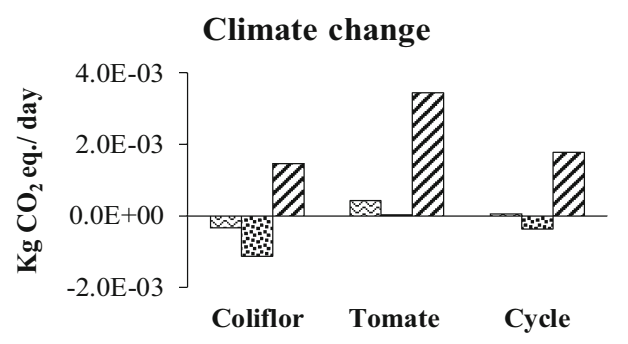

Terrestrial acidification

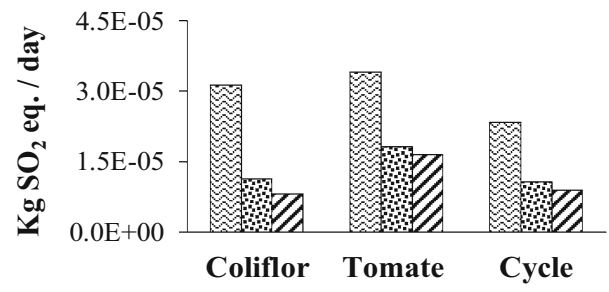

Marine eutrophication

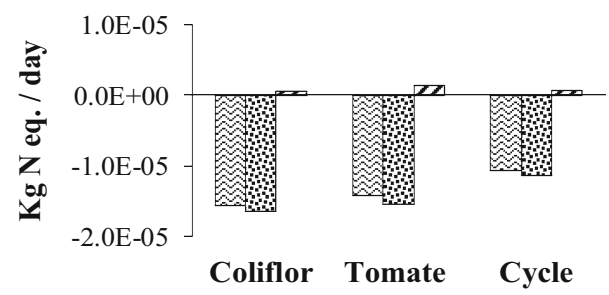

Cumulative energy demand

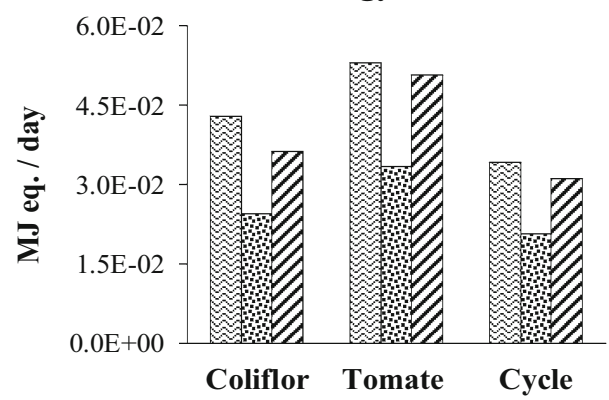

Photochemical oxidation

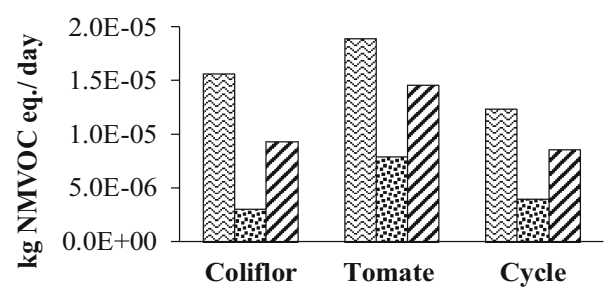

Freshwater eutrophication

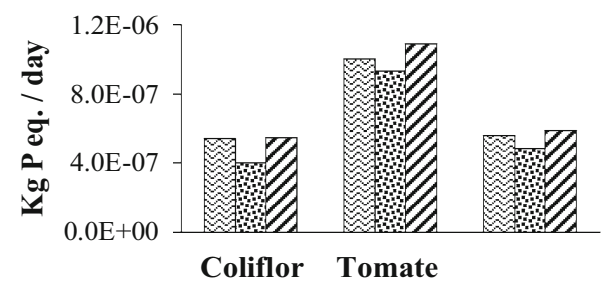

Fossil depletion

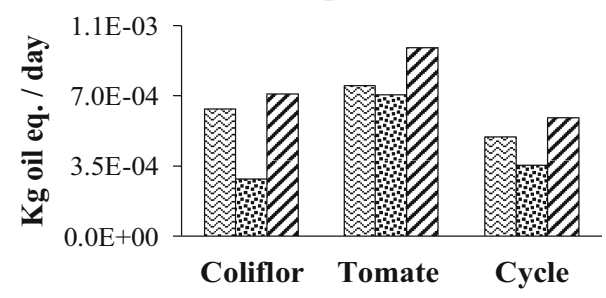

required a significant use of machinery in the soil due to the tillage operations required to apply and prepare the soil for the cultivations steps.

The fertilization treatment with $\mathrm{HC}$ yielded the best results than the fertilization treatment with IC and MF in all impact categories, with the exception of TA, in which MF had the lowest impact. The main pollutant contributors for the TA category are the emissions of $\mathrm{NH} 3$ and NOx. These emissions were considered in compost production (Quirós et al. 2014b) and the cultivation phase for both crops (i.e., cauliflower and tomato), as shown in Supplementary Data Table S2.

With regard to the allocation procedure, as shown in Fig. 3, the crops (cauliflower and tomato) fertilized with IC and Ta (i.e., allocation procedure based on the cultivation time) exhibited the greatest environmental impact in all categories, with the exception of CC and ME, in which the largest impact was observed for NMA (i.e., allocation procedure based on the degree of $\mathrm{N}$ mineralization). The impact values ranged from 7 to $14 \%$ depending on the crop and the category. For the crops fertilized with HC, the NMa procedure showed the greatest impact in all categories. For this case, the impacts ranged from 1 to $14 \%$ depending on the crop and the category. In our study, an opposite trend was observed when analyzing the results according to the allocation procedure. The compost production stages for HC exhibited a low contribution in the total impacts $(<10 \%)$, whereas the impact of the contri- 
bution of those stages (i.e., compost production plus transportation) ranged from 12 to $50 \%$ for IC, which resulted in a greater contribution in the compost production stage and a lower contribution in the cultivation stages. Therefore, Ta yielded better results with a low incidence in the compost production (HC), whereas NMa yielded a high contribution to the production process (IC).

To examine the potential environmental benefits of the entire crop cycle regarding the individual crops, the impacts were calculated per day for the two crops and for each fertilization treatment and for the entire crop cycle (i.e., sum of impacts of both crop), as shown in Fig. 4. The impacts of the entire horticultural cycle were lower than the individual crop in the majority of categories. However, the large differences between the cycle and the tomato crop were attributed to the greater impact that this crop exhibited compared with cauliflower. As explained in previous sections, the tomato crop received more irrigation and a larger application of mineral fertilizer.

The agronomical and environmental performance of cropping systems is the result of a complex interrelation of variables, such as crop type, weather, fertilizer type and crop management. The interrelation of the variables is a key factor for a sustainable crop sequence. We observed that the fertilization with MF for both crops (cauliflower and tomato) was superior to the fertilization with organic matter (IC and HC). However, the environmental performance of the crop fertilized with organic fertilizer (HC) was better than the crop fertilized with MF. We observed that the yield of crops is highly dependent on the nutrients supplied to the crops and the grade of the $\mathrm{N}$ mineralization in the soil. The nutrient supply is dependent on several variables, such as the weather conditions (rainfall), irrigation water, the nutrient content (nitrogen) in fertilizers, the allocation methods for applying compost to the crops and the horticultural management practices. In our study, no studies of a similar production and application of fertilizer to crops were identified for the comparison of the results. Martínez-Blanco et al. (2011) obtained higher yields for cauliflower and tomato crops that were cultivated in the same plots as the plots in our study. However, the horticultural results were obtained for crops cultivated in different conditions, such as crop management, cycles and varieties, sourcing of compost, nutrient concentration in compost, irrigation, doses and weather conditions.

Although the N concentration in IC was $47 \%$ higher than the $\mathrm{N}$ concentration $\mathrm{HC}$ (Table 1), the final $\mathrm{N}$ applied to the crops was very similar for both fertilization treatments (IC and $\mathrm{HC}$ ) due to the quantity of compost that was applied to the $\mathrm{HC}$ to compensate for the $\mathrm{N}$ concentration that was registered for the IC.

The $\mathrm{N}$ mineralization rate is considered to be one of the main factors for nutrient supply to crops. In a study of gross nitrogen in pulse crop rotation, mineralization was determined to be highly variable in a crop rotation (BedardHaughn et al. 2013). The total N provided to crops varied according to the fertilization treatment, the crop and the allocation procedure for the applied compost (Table 1). The quantity of $\mathrm{N}$ that was applied considerably varied with the crop type (i.e., the $\mathrm{N}$ applied to the tomato crop was two times larger than the $\mathrm{N}$ applied to the cauliflower crop, with the exception of the mineral fertilizer).

The balance between the nutrient requirements of the crop and the $\mathrm{N}$ concentration in the soil for horticultural crops because a large application of $\mathrm{N}$ to a crop will not always guarantee a greater crop yield. The $\mathrm{N}$ uptake was very similar for the same crop with an average of $27 \mathrm{gN} \mathrm{m}^{2}$ for cauliflower crops and $21 \mathrm{gN} \mathrm{m}^{-2}$ for tomato crops for the three fertilization treatments (IC, HC and MF) (Table 3). Regardless of the allocation procedure, the supplied $\mathrm{N}$ was on the order of 7.5 and $16 \mathrm{gN} \mathrm{m}^{-2}$ for cauliflower crops and tomato crops, respectively. Therefore, an approximate balance shows that almost 20 and $4 \mathrm{gN} \mathrm{m}^{-2}$ for cauliflower crops and tomato crops, respectively, were supplied from the $\mathrm{N}$ storage in soil. For MF, the $\mathrm{N}$ uptake by the cauliflower was 27 and $21 \mathrm{gN} \mathrm{m}^{2}$ for cauliflower crops and tomato crops, respectively, whereas the total $\mathrm{N}$ supplied to the crops was $5 \mathrm{gN} \mathrm{m}^{-2}$ for the cauliflower crop and $23 \mathrm{gN} \mathrm{m}^{-2}$ for the tomato crop, respectively. The net balance revealed that $21 \mathrm{gN} \mathrm{m}^{-2}$ was extracted from the soil in the case of the cauliflower crop and the tomato crop exceeded the $\mathrm{N}$ requirements by approximately $2 \mathrm{gN} \mathrm{m}^{-2}$, which is expected to remain in the ground for future crops. This significant provision of $\mathrm{N}$ from the soil in the case of mineral fertilizer for the cauliflower crop should be considered to be a negative environmental effect because the soil lost an important source of nutrients.

Several authors have noted the benefits of compost when it is applied to crops: It enhances the soil aggregate stability and reduces the risk of erosion (Annabi et al. 2011); it increases soil porosity (Hargreaves et al. 2008); and it releases nutrients including $\mathrm{C}$ and $\mathrm{N}$ (Benitez et al. 2003). However, the levels of $\mathrm{N}$ in the applied compost (1-2.5\% $\mathrm{N}$-Kjeldahl), which are considerably lower than the inorganic fertilizer (14\% of $\mathrm{N}$ in $\mathrm{KNO}_{3}$ ), required a high quantity of compost to compensate for the differences in $\mathrm{N}$. As in our study case, Thangarajan et al. (2013) obtained 
low levels of $\mathrm{N}$ in compost that ranged from; they obtained $46 \% \mathrm{~N}$ for inorganic fertilizers (Urea). Although beneficial, compost production and application are associated with some risks and problems, such as contamination by heavy metals, salts, weed seeds, and pathogens (Chan et al. 2007). In addition, the major concern of composting is the loss of $\mathrm{C}$ and $\mathrm{N}$, which decreases the agronomic value of compost and also contributes to GHG and other environmental impacts, such as eutrophication (freshwater and marine) and terrestrial acidification.

\section{Conclusion}

This study evaluated a crop sequence of tomato and cauliflower for a 1-year cycle using the LCA methodology. Organic and mineral fertilizer can be used as a mineral substitute in crops. The home compost showed the best environmental performance compared with industrial compost and mineral fertilizer in the majority of the impact categories, with the exception of terrestrial acidification and marine eutrophication. Emissions, which were produced by the compost degradation in soil by biological activity, represent the main contributor in those categories. A better environmental performance was achieved for the horticultural systems with the allocation procedure based on the cultivation time compared with the degree of mineralization in the soil. The crops fertilized with IC yielded better environmental results (less impact per category) than the crops fertilized with $\mathrm{HC}$ when considering the allocation procedure based on the degree of $\mathrm{N}$ mineralization in the soil. The compost production stage had a great contribution to the total environmental impacts for this fertilizer. The environmental analysis showed better results for the entire cycle of the crop sequence than the individual crops in the majority of the categories. In terms of the agronomical results, the mineral fertilizer produced higher yields than the crop fertilized with home and industrial compost. This yield is attributed to the immediate availability of nutrients for plants because the nutrients are already mineralized as $\mathrm{KNO}_{3}$ at the time of application. In the case of organic fertilizer, the mineralization of nitrogen gradually occurs over time; thus, the nutrients are not immediately available to the crops. Similarly, the mineralization process is dependent on other conditions, such as the maturity and stability of the compost, weather conditions, soil type, horticultural management and the nutrient concentration in the compostable material.
Future studies are recommended in the same field plots in which this experiment was conducted to evaluate and validate the results of this study, such as the degree of $\mathrm{N}$ mineralization in the soil. Future studies of a crop rotation in the same field, in which variables such as weather conditions, seasons, organic fertilizer composition and horticultural management are varied and tested, are needed.

Acknowledgments The principal author expresses his thanks for awards and scholarships from Erasmus Mundus E2NHANCE PROJECT EU, Universidad de Costa Rica and CONICIT (Comisión Nacional de Investigaciones Científicas y Tecnológicas de Costa Rica). Financial support was provided by the European Union Interreg Project (ECOTECH-SUDOE SOE2/P2/E377) with a total of $€ 500 \mathrm{k}$. The authors thank to Recerca i Tecnologia Agroalimentáries (IRTA) and Grupo de Investigación en Compostage (GICOM) at the Universidad Autónoma de Barcelona for their collaboration in suppling data of field trials.

\section{References}

Annabi M, Le Bissonnais Y, Le Villio-Poitrenaud M, Houot S (2011) Improvement of soil aggregate stability by repeated applications of organic amendments to a cultivated silty loam soil. Agric Ecosyst Environ 144:382-389

Audsley E (2007) Harmonisation of environmental life cycle assessment for agriculture. Final report concerted action AIR 3-CT94-2028. European Commission DG VI Agriculture, Silsoe

Ayari F, Hamdi H, Jedidi N, Gharbi N, Kossai R (2010) Heavy metal distribution in soil and plant in municipal solid waste compost amended plots. Int J Environ Sci Technol 7(3):465-472

Bedard-Haughn A, Comeau L, Sangster A (2013) Gross nitrogen mineralization in pulse-crop rotations on the Northern Great Plains. Nutr Cycl Agroecosystems 95(2):159-174

Benitez C, Tejada M, Gonzalez JL (2003) Kinetics of the mineralization of nitorgen in a pig slurry compost applied to soils. Compost Sci Util 11:72-80

Bernat C, Casado D, Ferrando C, Paulet S, Pujol M, Soliva M (2000) Compost, manure and sewage sludge applied to a crop rotation. In: Sangiorgi F (ed) Ramiran 2000, Proceedings of the 9th international workshop of the network general theme technology transfer. University of Milan, Institute of Agricultural Engineering, pp 231-236

Casals JL, Pascual L (2011) The risks of success in quality vegetable markets: possible genetic erosion in marmande tomatoes (Solanum lycopersicum L.) and consumer dissatisfaction. Sci Hortic 130:78-84

Chan K, Dorahy C, Tyler S (2007) Determining the agronomic value of composts produced from garden organics from metropolitan areas of New South Wales, Australia. Aust J Exp Agric 47:1377

Colón J, Cadena E, Pognani M et al (2012) Determination of the energy and environmental burdens associated with the biological treatment of source-separated municipal solid wastes. Energy Environ Sci 5:5731 
Doka G (2007) Life cycle inventories of waste treatment services. Ecoinvent report No. 13. Swiss Centre for Life Cycle Inventories, Dübendorf, Switzerland

Doltra J, Muñoz P (2010) Simulation of nitrogen leaching from a fertigated crop rotation in a Mediterranean climate using the EURotate_N and Hydrus-2D models. Agric Water Manag 97:277-285

Ehrmann J, Ritz K (2013) Plant: soil interactions in temperate multicropping production systems. Plant Soil 376:1-29

Ekvall T, Tillman A (1997) Open-loop recycling: criteria for allocation procedures. Int J Life Cycle Assess 2:155-162

European Commission (1999) EU Directive 1999/31/EC, 1999. Official Journal of the European Communities, L 182

European Commission (2008) Green paper on the management of bio-waste in the European Union

European Economic Community (1991) Directive 91/676/ECC, of 12 December 1991 concerning the protection of waters against pollution caused by nitrates from agricultural sources. Off J Eur Commun

Frischknecht R, Jungbluth N (2003) Implementation of life cycle impact assessment methods. Ecoinvent report N3, v2.0. Swiss Centre for Life Cycle Inventory, Dübendorf, Switzerland

Gaillard G, Hausheer J (1999) Ökobilanz des Weizenanbaus. Agrarforschung Band 6(1):37-40

Hansen TL (2006) Environmental modelling of use of treated organic waste on agricultural land: a comparison of existing models for life cycle assessment of waste systems. Waste Manag Res 24:141-152

Hargreaves J, Adl M, Warman P (2008) A review of the use of composted municipal solid waste in agriculture. Agric Ecosyst Environ 123:1-14

Hayer F, Bonnin E, Carrouée B, Gaillard G, Nemecek T (2010) Designing sustainable crop rotations using life cycle assessment of crop combinations. 9th European IFSA, Symposium, 4-7 July 2010, Viena, Austria, 903-911. http://ifsa.boku.ac.at/cms/ fileadmin/Proceeding2010/2010_WS2.1_Hayer.pdf. Accessed 15 May 2014

IPCC (Intergovernmental Panel on Climate Change). (2006) Guidelines for National Greenhouse Gas Inventories. http://www.ipccnggip.iges.or.jp/public/2006gl/index.htm. Accessed 15 Oct 2013

Iqbal MK, Nadeem A, Sherazi F, Khan R (2014) Optimization of process parameters for kitchen waste composting by response surface methodology. Int J Environ Sci Technol. doi:10.1007/ s13762-014-0543-x

ISO 14040 (2006) Environmental management e life cycle assessment e requirements and guidelines. Geneva, Switzerland

ISO 14044 (2006) Environmental management-life cycle assessment-requirements and guidelines. ISO, Geneva

Keeney D, Nelson D (1982) Nitrogen inorganic form. In: Page AL, Miller RH, Keeney DR (eds) Methods of soil analysis part II. ASA, Madison, pp 643-698

Laegreid M, Bockman O, Kaarstad O (1999) Agriculture, fertilizers and the environment. CABI Publishing, Wallingford

Lim SL, Wu TY, Clarke C (2014a) Treatment and biotransformation of highly polluted agro-industrial wastewater from a palm oil mill into vermicompost using earthworms. J Agric Food Chem 62:691-698

Lim SL, Wu TY, Lim PN, Shak KPY (2014b) The use of vermicompost in organic farming: overview, effects on soil and economics. J Sci Food Agric. doi:10.1002/jsfa.6849
Lleó T, Albacete E, Barrena R et al (2013) Home and vermicomposting as sustainable options for biowaste management. J Clean Prod 47:70-76

Lombardi L, Carnevale E (2013) Comparison of different biological treatment scenarios for the organic fraction of municipal solid waste. Int J Environ Sci Technol. doi:10.1007/s13762-013-0421y

Makan A, Assobhei O, Mountadar M (2014) Initial air pressure influence on in-vessel composting for the biodegradable fraction of municipal solid waste in Morocco. Int J Environ Sci Technol $11: 53-58$

Martínez-Blanco J, Muñoz P, Antón A, Rieradevall J (2011) Assessment of tomato Mediterranean production in open-field and standard multi-tunnel greenhouse, with compost or mineral fertilizers, from an agricultural and environmental standpoint. J Clean Prod 19:985-997

Martínez-Blanco J, Rieradevall J, Antón A, Muñoz P (2014) Multifunctionality-solving approaches of compost application in crop rotations. J Clean Prod 64:384-395

Ministerio de la Presidencia (2013) Royal Decree 506/2013, on fertilizing products (in Spanish)

Ongley E (1996) Control of water pollution from agriculture. FAO irrigation and drainage paper no.55. FAO, Rome

Perrin A, Basset-Mens C, Gabrielle B (2014) Life cycle assessment of vegetable products: a review focusing on cropping systems diversity and the estimation of field emissions. Int J Life Cycle Assess 19(6): 1247-1263

PRé Consultants (2013) SimaPro Software Versión 7.3.3. PRé Consultants, The Netherlands

Quirós R, Villalba G, Muñoz P et al (2014a) Environmental and agronomical assessment of three fertilization treatments applied in horticultural open field crops. J Clean Prod 67:147-158

Quirós R, Villalba G, Muñoz P, Colón J, Font X, Gabarrell X (2014b) Environmental assessment of two home composts with high and low gaseous emissions of the composting process. Resour Conserv Recycl 90:9-20

RuralCat (2013) Xarxa Agrometeorològica de Catalunya. (Catalan Agricultural Mete orology Net). http://www.ruralcat.net/web/ guest/agrometeo.estacions?. Consulted on December 15th, 2013

Shak KPY, Wu TY, Lim SL, Lee CA (2014) Sustainable reuse of rice residues as feedstocks in vermicomposting for organic fertilizer production. Environ Sci Pollut Res 21:1349-1359

Smith A, Brown K, Ogilvie S, Rushton K, Bates J (2001) Waste management options and climate change. Final report to the European Commission, DG Environment. Office for Official Publications of the European Communities, Luxembourg

Sudharsan V, Kalamdhad S (2014) Evolution of chemical and biological characterization during thermophilic composting of vegetable waste using rotary drum composter. Garajan. doi:10. 1007/s13762-014-0582-3

Swiss Centre for Life Cycle Inventories (2013) Ecoinvent Data v2.1. Dübendorf

Thangarajan R, Bolan NS, Tian G, Naidu R, Kunhikrishnan A (2013) Role of organic amendment application on greenhouse gas emissions from soil. Sci Total Environ 465:72-92

Wu TY, Lim SL, Lim PN, Shak KPY (2014) Biotransformation of biodegradable solid wastes into organic fertilizers using composting or/and vermicomposting. Chem Eng Trans 39:1579-1584 
Zaman AU (2013) Identification of waste management development drivers and potential emerging waste treatment technologies. Int J Environ Sci Technol 10(3):455-464

Zhou M, Zhu B, Brüggemann N, Bergmann J, Wang Y, ButterbachBahl K (2013) $\mathrm{N}_{2} \mathrm{O}$ and $\mathrm{CH}_{4}$ emissions, and $\mathrm{NO}_{3}$-leaching on a crop-yield basis from a subtropical rain-fed wheat-maize rotation in response to different types of nitrogen fertilizer. Ecosystem $17: 286-301$ 